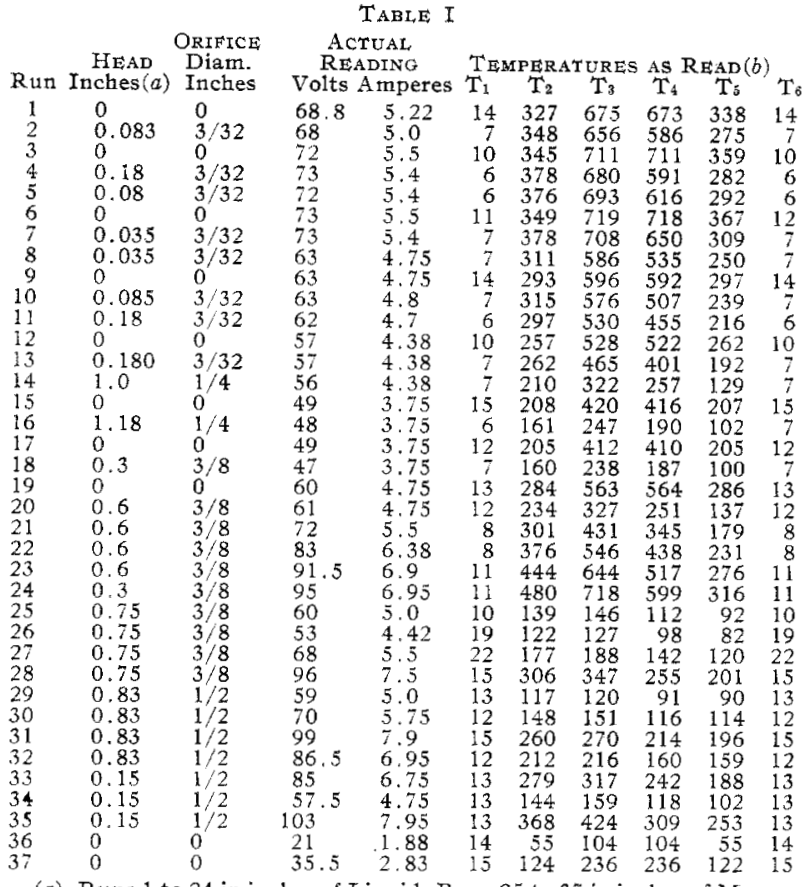

(a) Runs 1 to 24 in inches of Liquid; Runs 25 to 37 in inches of Mercury. (b) $T_{2}$ to $T_{b}$, as read by thermal-coupl
water bath at opposite etds of the furnace.

through each square foot of section. the section being taken at right angles to both heating surface and direction of flow of the air. The expression is apparently independent of temperature up to $750^{\circ} \mathrm{F}$.

In the derivation of this formula we have expressed velocities as 1bs. of air per sq. ft. of section of path per second. Our reason is that otherwise velocity past various points in the path of flow is a variable

\begin{tabular}{|c|c|c|c|c|c|c|c|}
\hline \multirow[b]{2}{*}{ Group } & \multirow[b]{2}{*}{ Run } & \multicolumn{3}{|c|}{ TABLE II } & \multirow[b]{2}{*}{ Volts } & \multirow{2}{*}{ CORRECTEI } & \multirow[b]{2}{*}{ WATTS } \\
\hline & & Sq. in. & In. & : & & & \\
\hline$\ldots$ & $\begin{array}{l}33 \\
34 \\
35\end{array}$ & $\begin{array}{r}18.20 \\
8.72 \\
24.32\end{array}$ & $\begin{array}{l}2.43 \\
1.16 \\
3.24\end{array}$ & $\begin{array}{l}243 \\
116 \\
324\end{array}$ & $\begin{array}{r}83.3 \\
55.5 \\
101.3\end{array}$ & $\begin{array}{r}6.65 \\
4.60 \\
7.85\end{array}$ & $\begin{array}{l}554 \\
255 \\
795\end{array}$ \\
\hline$A_{2}, \ldots \ldots$ & $\begin{array}{r}2 \\
10 \\
5\end{array}$ & $\begin{array}{l}37.48 \\
32.80 \\
39.75\end{array}$ & $\begin{array}{l}4.99 \\
4.37 \\
5.30\end{array}$ & $\begin{array}{l}499 \\
437 \\
530\end{array}$ & $\begin{array}{l}66.0 \\
61.5 \\
70.0\end{array}$ & $\begin{array}{l}4.87 \\
4.65 \\
5.28\end{array}$ & $\begin{array}{l}321 \\
286 \\
370\end{array}$ \\
\hline $\mathrm{B}_{1} \ldots \ldots \ldots$ & $\begin{array}{l}29 \\
30 \\
31 \\
32\end{array}$ & $\begin{array}{r}6.64 \\
8.71 \\
16.07 \\
12.67\end{array}$ & $\begin{array}{l}8.85 \\
1.16 \\
2.14 \\
1.69\end{array}$ & $\begin{array}{l}885 \\
116 \\
214 \\
169\end{array}$ & $\begin{array}{l}57.3 \\
68.0 \\
97.3 \\
84.7\end{array}$ & $\begin{array}{l}4.80 \\
5.65 \\
7.75 \\
6.85\end{array}$ & $\begin{array}{l}275 \\
385 \\
755 \\
580\end{array}$ \\
\hline $\mathrm{B}_{2}, \ldots \ldots$ & $\begin{array}{l}20 \\
21 \\
22 \\
23\end{array}$ & $\begin{array}{l}17.65 \\
24.00 \\
29.92 \\
36.05\end{array}$ & $\begin{array}{l}2.35 \\
3.20 \\
3.99 \\
4.81\end{array}$ & $\begin{array}{l}235 \\
320 \\
399 \\
481\end{array}$ & $\begin{array}{l}59.0 \\
70.0 \\
81.2 \\
89.3\end{array}$ & $\begin{array}{l}4.60 \\
5.40 \\
6.28 \\
6.80\end{array}$ & $\begin{array}{l}271 \\
378 \\
510 \\
608\end{array}$ \\
\hline$C_{1} \ldots \ldots \ldots$ & $\begin{array}{l}25 \\
26 \\
27 \\
28\end{array}$ & $\begin{array}{r}8.33 \\
6.55 \\
10.05 \\
19.38\end{array}$ & $\begin{array}{l}1.11 \\
8.73 \\
1.3 \frac{1}{2} \\
2.58\end{array}$ & $\begin{array}{l}111 \\
873 \\
134 \\
258\end{array}$ & $\begin{array}{l}58.0 \\
51.0 \\
66.0 \\
94.3\end{array}$ & $\begin{array}{l}4.87 \\
4.30 \\
5.40 \\
7.42\end{array}$ & $\begin{array}{l}282 \\
218 \\
356 \\
700\end{array}$ \\
\hline $\mathrm{C}_{2} \ldots \ldots \ldots$ & $\begin{array}{l}18 \\
24\end{array}$ & $\begin{array}{l}12.96 \\
41.19\end{array}$ & $\begin{array}{l}1.73 \\
5.49\end{array}$ & $\begin{array}{l}173 \\
549\end{array}$ & $\begin{array}{l}45.0 \\
93.3\end{array}$ & $\begin{array}{l}3.55 \\
6.85\end{array}$ & $\begin{array}{l}160 \\
639\end{array}$ \\
\hline $\mathrm{D}_{1}, \ldots \ldots$ & $\begin{array}{l}14 \\
16\end{array}$ & $\begin{array}{l}17.65 \\
13.50\end{array}$ & $\begin{array}{l}2.35 \\
1.80\end{array}$ & $\begin{array}{l}235 \\
180\end{array}$ & $\begin{array}{l}53.5 \\
46.0\end{array}$ & $\begin{array}{l}4.23 \\
3.55\end{array}$ & $\begin{array}{l}227 \\
163\end{array}$ \\
\hline $\mathrm{D}_{2} \ldots \ldots \ldots$ & $\begin{array}{r}4 \\
11 \\
13\end{array}$ & $\begin{array}{l}38.79 \\
29.84 \\
26.07\end{array}$ & $\begin{array}{l}5.17 \\
3.98 \\
3.48\end{array}$ & $\begin{array}{l}517 \\
398 \\
348\end{array}$ & $\begin{array}{l}71.0 \\
60.0 \\
55.0\end{array}$ & $\begin{array}{l}5.28 \\
4.55 \\
4.23\end{array}$ & $\begin{array}{l}375 \\
273 \\
233\end{array}$ \\
\hline Blanks.... & $\begin{array}{r}1 \\
3 \\
6 \\
9 \\
12 \\
15 \\
17 \\
19 \\
36 \\
37\end{array}$ & $\begin{array}{r}40.36 \\
43.03 \\
43.59 \\
35.45 \\
31.58 \\
24.78 \\
24.46 \\
33.95 \\
5.41 \\
14.37\end{array}$ & $\begin{array}{l}5.38 \\
5.74 \\
5.81 \\
4.73 \\
4.21 \\
3.31 \\
3.26 \\
4.53 \\
0.72 \\
1.91\end{array}$ & $\begin{array}{r}538 \\
574 \\
581 \\
473 \\
421 \\
331 \\
326 \\
453 \\
72 \\
191\end{array}$ & $\begin{array}{l}67.0 \\
70.0 \\
71.0 \\
61.0 \\
65.0 \\
47.5 \\
47.0 \\
58.0 \\
18.9 \\
33.5\end{array}$ & $\begin{array}{l}5.10 \\
5.40 \\
5.40 \\
4.60 \\
4.23 \\
3.54 \\
3.55 \\
4.60 \\
1.65 \\
2.63\end{array}$ & $\begin{array}{r}342 \\
378 \\
383 \\
281 \\
233 \\
166 \\
167 \\
267 \\
31 \\
88\end{array}$ \\
\hline
\end{tabular}

quantity owing to the expansion of the gas in heating. On the assumption that the resistance to flow of heat from a solid to air is due to a surface film of gas around the solid and that the increase in heat conductivity with increasing velocity is caused by the ripping off

$\begin{array}{ccccc}\begin{array}{c}\text { Av. Temp. } \\ \text { of Furnace }\end{array} & \begin{array}{c}\text { Tout Net } \\ \text { Watts }\end{array} & \begin{array}{c}\text { Temp. Exit } \\ \text { Gas }\end{array} & \begin{array}{c}\text { Average Temp. } \\ \text { Difference }\end{array} & \begin{array}{c}\text { Value } \\ \text { of "K" }\end{array} \\ 111 & 253 & 80.7 & 53.3 & 3.84 \\ 161 & 380 & 108.7 & 87.5 & 3.52 \\ 211 & 523 & 140.0 & 119.0 & 3.56 \\ 261 & 652 & 171.0 & 151.0 & 3.54 \\ 311 & 804 & 202.0 & 183.0 & 3.56 \\ 361 & 925 & 229.0 & 218.0 & 3.44\end{array}$

of this film, the shearing effect upon this film should be determined by the mass of gas passing the heating. surface in unit time rather than by its linear velocity, and the use of the above unit of velocity is rational. The constancy of the results of our calctlations by this method are, however, its best justification.

We believe that the above equation represents the best figure which is at present available to employ

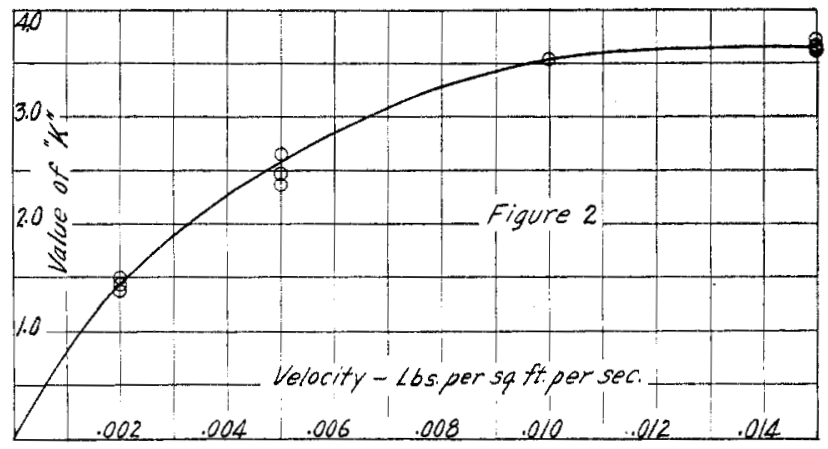

for the value of $K$ from solids to ait and feel that it is decidedly preferable to the figure of Richards, the one hitherto most frequently employed, because Richards' formula indicates indefinitely high values at high velocities, whereas our formula indicates, as the experimental results show, that at high velocities the value of $K$ reaches a limiting value beyond which it cannot rise.

Researca Laboratory of ApPlied Chemistry

Massachusets Institute of Technology

\section{LABORATORY PROBLEMS IN INDUSTRIAL CHEMISTRY} By $\mathrm{H}, \mathrm{K}$. BENSON

Received March 23, 1916

The field of industrial chemistry is so large that the planning of courses in this subject involves many factors. It has been the experience of the writer that instructors in industrial chemistry formulate their courses largely from the standpoint of their previous personal experience. It is believed that an exchange of views detailing the practice followed by various instructors would prove of great value to individuals as well as be an aid in standardizing the subject matter and in working towards some degree of uniformity.

With this end in view a series of problems are here outlined showing the character of training furnished by such problems. Such a course is not to be regarded as ideal but rather is proposed as an aid to a discussion that might be of value to those who are feeling their way along paths that are not as yet well defined.

The problems were assigned to chemistry students of Junior standing. They had completed courses in general inorganic chemistry, qualitative analysis, quantitative analysis, and were taking organic chemistry coincident with industrial chemistry. The general plan followed was the statement of the problem by 
the instructor after which the student was expected to devise his own methods for solution. The instructor answered specific questions but refused to suggest an outline or general plan of procedure, requiring the student to work out his own methods from the literature. A full discussion and exchange of methods among the students in the laboratory was, however, encouraged. Experience has shown that students attack such problems in a wide variety of ways and frequently with varying results. These are criticized and amended in class discussions at the end of each semester.

PROBLEM I-Given a sample of crude California petroleum, obtain the yield of kerosene oil which complies with the requirements of the state law.

Requirements: An examination of the state law, reference to the literature of petroleum refining and familiarity of the student with the varying effects of the rate of distillation, the design of distilling apparatus, the effects of acid and alkali treatment, the removal of water from oily distillates, and the various forms of oil testing apparatus.

PROBLEM II-Given a sample of coal-gas tar at a local cost of 6 cents per gallon, determine the yield of creosote complying with the specifications of the city of Seattle and the cost per gallon, f. o. b. plant, of the creosote.

Requirements: The specifications of the city for creosote, the distillation of the coal tar, computation of fractions and the derivation of the process of distillation, the analysis of the creosote by the official method, a study of the uses and values of the by-products such as light oil and pitch, the selection of a unit charge for commercial operation, a field study of a Barrett plant, and itemization of costs of production.

PROBLEM III-Prepare a bituminous enamel containing 20-35 per cent carbonaceous matter insoluble and $55^{-6} 5$ per cent ash, with physical properties specified by the United States War Department.

Requirements: A study. of the commercial pitches, methods of analysis of bituminous materials and selection of a paint filler.

PROBLEM IV-Determine which one of two commercial boiler compounds shall be selected to prevent scale formation in the University Power Station.

Requirements: Analysis of scale, of feed water and of the boiler compounds; a study of the causes and prevention of scale formation and the application of the data to the given case. A description of the problem has already been published in THIs JournaL, 8 (I9I6), 435 .

PROBLEM V-Determine the effect of blending Portland cement with Washington tufa.

Requirements: Reference to the literature of blended cement products; testing of cement by standard methods; and a study of cement specifications.

PROBLEN VI-Determine the proportion of cement, sand and gravel in concrete.

Requirements: Method of mechanical analysis; grading of aggregate; specific gravity determinations; chemical analysis of cement; and computations.
PROBLEM VII-Determine the effect of adding lime and sand to a plastic red burning clay.

Requirements: Methods of clay testing; study of range of vitrification; grinding and mixing operations.

PROBLEM VIII-Classify the oil obtained from samples of Philippine nuts.

Requirements: Extraction of oil from nuts; comparison with the known constants of fatty oils; and the relation of constants to uses of the oil.

PROBLEM IX-Determine the yield of rosin in western yellow pine.

Requirements: Methods of sampling; extraction by various solvents; and efficiency of commercial solvents.

PROBLEM $\mathrm{X}$-Determine the efficiency of the recovery of ammonia in the extraction of rosin from Douglas fir.

Requirements: Separation of rosin and humus; Kjeldahl determinations; removal of ammonia from wood; and computations.

PROBLEM XI-Devise a method for the extraction of cedar oil from the destructive distillation of Port Orford cedar and determine the nature and probable uses of the residues of the distillate.

Requirements: Methods of steam distillation and of vacuum distillation; study of literature relating to Port Orford cedar oil; determination of constants of oil; study of wood tars and their uses.

PROBLEM XII-Prepare a rosin paint drier soluble in raw linseed oil.

Requirements: Preparation of metallic resinates; methods of paint testing; and commercial requirements of driers.

During the present year similar problems dealing with the study of cactus, wood humus, potash salts, recovery of iodine, cost of manufacture of hypochlorites, etc., have been undertaken. It is apparent that the problems are capable of great diversification, which adds to the interest. The chief objects in view are to throw the student upon his own resources, make him acquainted with chemical literature and force him to make use of the tools of knowledge already in his possession.

LABORATORY OF INDUSTRTAL ChEMISTRy

UNIVERSITY OF WAShINGTON, SEATTLE

\section{AN UNUSUAL EXPLOSION IN CONNECTION WITH POTASSIUM CHLORATE \\ By Floyd E. Rowland \\ Received May 3, 1916}

There was nothing unusual about the explosion itself, but the manner in which it occurred is well worth mentioning and bringing to the attention of all who have occasion to use pestles which have wooden handles.

Everyone knows that disaster is sure to follow when potassium chlorate and sulfur are ground together; but to have a perfectly clean mortar and pestle suddenly explode with great violence, when one is grinding an inert substance like pumice stone, makes one pause and wonder why.

A pestle and an 8-inch mortar were thoroughly cleaned and about fifteen pounds of potassium chlorate were ground with no disastrous results. The mortar 